\title{
ANALISIS KEUNTUNGAN USAHA GORENGAN "IBU NOUKE" DI KELURAHAN BAHU KECAMATAN MALALAYANG KOTA MANADO
}

\author{
Hutri Di Tambajong \\ Mex Frans Lodwyk Sondakh \\ Melissa Lady Gisela Tarore
}

\begin{tabular}{ll}
\hline Naskah diterima melalui Website Jurnal Ilmiah agrisosioekonomi@ unsrat.ac.id & $:$ Kamis, 09 Januari 2020 \\
Disetujui diterbitkan & $:$ Sabtu, 11 Januari 2020 \\
\hline
\end{tabular}

\begin{abstract}
The purpose of this study is to analyze the benefits received by the fried home business industry in a single production process. This research was conducted in the Village Shoulder, Malalayang District, Manado City. This research was conducted for 3 months from October to December 2019. The data used in this study were primary and secondary data. Primary data was collected using direct interview techniques with business owners with the help of a list of questions prepared in advance. Data collected in this study were then analyzed using profit analysis using the formula for Revenue Cost Ratio $(R / C)$ analysis. The results showed that the fried food business in the Village of Bahu, Bunaken District, Manado City was very profitable and got an $R / C$ value of 1.35, which meant the industry was profitable and feasible to be developed. ${ }^{\text {eprm* }}$
\end{abstract}

Keywords: fried food business, profit analysis, $R / C$ ratio, Bahu Urban Vilage

\begin{abstract}
ABSRAK
Tujuan penelitian ini adalah menganalisis keuntungan yang diterima industri rumah tangga usaha gorengan dalam satu kali proses produksi. Penelitian ini dilakukan di Kelurahan Bahu, Kecamatan Malalayang Kota Manado. Penelitian ini dilakukan selama 3 bulan dari bulan Oktober sampai bulan Desember 2019. Data yang digunakan dalam penelitian ini berupa data primer dan sekunder. Data primer dikumpulkan menggunakan teknik wawancara langsung dengan pemilik usaha dengan bantuan daftar pertanyaan yang telah dipersiapkan terlebih dahulu. Data yang dikumpulkan dalam penelitian ini kemudian dianalisis dengan menggunakan analisis keuntungan dengan menggunakan rumus Analisis Revenue Cost Ratio (R/C). Hasil penelitian menunjukkan bahwa usaha gorengan di Kelurahan Bahu, Kecamatan Bunaken, Kota Manado sangat menguntungkan dan mendapat nilai $\mathrm{R} / \mathrm{C}=1,35$ yang berarti industri ini menguntungkan dan layak untuk dikembangkan. ${ }^{*}$ prm*
\end{abstract}

Kata kunci: usaha gorengan, analisis keuntungan, R/C ratio, Kelurahan Bahu

Agrisosioekonomi: 


\section{PENDAHULUAN}

Indonesia adalah negara agraris yang sebagian besar penduduknya hidup dari hasil bercocok tanam atau bermata pencaharian di bidang pertanian. Hingga kini mayoritas penduduk Indonesia telah memanfaatkan sumber daya alam untuk menunjang hidupnya dan menggantungkan hidupnya pada sektor pertanian. Sektor pertanian memiliki peranan yang sangat penting karena sebagai penghasil bahan pangan bagi penduduk yang jumlah tiap tahunnya terus bertambah, sebagai penyedia bahan baku untuk industri dan untuk perdagangan ekspor (Suparta, 2010).

Makanan gorengan yang dijajakan di pinggir jalan sangat menjadi primadona di Indonesia baik dikalangan masyarakat menengah ke atas ataupun menengah ke bawah. Gorengan menjadi primadona dikarenakan gorengan adalah makanan murah meriah dan memiliki cita rasa yang nikmat serta cocok dengan selera masyarakat pada umumnya (Cahanar dan Suhanda, 2006).

Bisnis kuliner termasuk yang menjadi pilihan banyak orang, karena di anggap jenis bisnis yang lebih mudah dilakukan dari pada jenis bisnis lainnya. Namun, bisnis kuliner termasuk bisnis yang tergolong rumit karena membutuhkan banyak inovasi dan kreatifitas yang berkelanjutan. Oleh karena itu, strategi berperan penting untuk dapat terus bersaing dalam industri ini, meski dalam lingkup usaha kecil.

Menurut Bardosono (2014), produksi pisang di Indonesia pada tahun 2013 telah mencapai 5,3 ton. Melimpahnya ketersediaan pisang menyebabkan pisang dirasakan bukanlah komoditas penting dan tidak memberikan nilai tambah bagi produsen pisang khususnya petani. Pisang juga merupakan komoditas hortikultura yang tidak memiliki daya simpan yang lama, sehingga apabila kemelimpahan pisang tidak diimbangi dengan pemanfaatnya maka akan meningkatkan potensi kebusukan komoditas tersebut (Adriani dan Nasriati, 2011).

Membuka usaha gorengan itu membutuhkan tekad yang giat dan terampil, karena dalam usaha gorengan itu sendiri membutuhkan tenaga kerja, para pekerja gorengan rata-rata berasal dari desa serta memiliki pendidikan yang rendah. Hal ini dapat menciptakan harapan bagi para masyarakat dengan pendidikan rendah dan juga dapat mengurangi tingkat pengangguran dalam memperbaiki taraf hidup masyarakat.
Makanan gorengan salah satu primado di Manado, baik di kalangan masyarakat menengah ke atas ataupun menengah ke bawah. Gorengan menjadi primadona di karenakan gorengan adalah makanan murah meriah dan memiliki cita rasa yang nikmat serta cocok dengan selera masyarakat pada umumnya.

Gorengan sangatlah identik dengan minyak goreng. Minyak goreng selain memberikan rasa gurih, dan menjadikan tampilan makanan menjadi lebih menarik. Selain itu minyak goreng juga memberikan milai kalori paling besar, di antara zat gisi lainnya. Namun pada pengolahan belum tentu minyak yang ada di gorengan tersebut baik di konsumsi manusia terutama anak-anak yang daya tahan tubuhnya belum sekuat daya tahan tubuh orang dewasa, maka proses penirisan sangatlah penting di lakukan. Penirisan pada gorengan di tujukan untuk mengurangi kadar minyak, dan menjaga kerenyahan gorengan.

\section{Faktor-faktor Pengembangan Usaha Gorengan}

Upaya pengembangan usaha gorengan memerlukan faktor-faktor yang menentukan suatu pengembangan usaha yang terencana dengan baik sehingga menghasilkan alternatifalternatif strategi yang merupakan alat untuk mencapai tujuan yang memiliki kaitannya dengan tujuan pengembangan usaha gorengan tersebut. Faktor-faktor yang mempengaruhi usaha gorengan sebagai berikut: konsep biaya, konsep produksi, konsep harga.

\section{Konsep Biaya}

Biaya adalah harga pokok yang telah memberi manfaat dan telah habis dimanfaatkan. Biaya dapat diartikan sebagai pengorbanan sumber ekonomi baik yang terwujud maupun tidak terwujud yang dapat ditukar dalam satuan uang, yang telah terjadi atau akan terjadi untuk mencapai tujuan tertentu. Biaya merupakan salah satu faktor penting dalam penentuan harga pokok produksi dan harga jual produksi.

Menurut Supriyono (2000) Biaya adalah harga perolehan yang digunakan dalam memperoleh penghasilan atau revenue yang akan dipakai sebagai pengurangan penghasilan. Biaya adalah kas atau nilai kas yang digunakan untuk barang atau jasa yang diharapkan memberi manfaat saat ini atau dimasa mendatang bagi organisasi (Simamora, 2000). 


\section{Konsep Produksi}

Produksi sering diartikan sebagai penciptaan guna, dimana kemampuan barang atau jasa untuk memenuhi kebutuhan manusia. Produksi meliputi semua aktifitas dan tidak hanya mencakup pembuatan barang-barang yang dapat dilihat. Produksi adalah suatu kegiatan untuk meningkatkan manfaat dengan cara mengkobinasikan faktor-faktor produksi capital, tenaga kerja, teknologi. Produksi merupakan usaha meningkatkan manfaat dengan cara mengubah bentuk, memindahkan tempat, dan menyimpan (Santoso, 2009).

Produksi adalah menciptakan, menghasilkan, dan membuat. Kegiatan produksi tidak akan dapat dilakukan kalau tidak ada bahan yang memungkinkan dilakukannya proses produksi itu sendiri. Untuk bisa melakukan produksi, orang memerlukan tenaga manusia, sumber-sumber alam, modal dalam segala bentuknya, semua unsur itu disebut faktor-faktor produksi. Jadi, semua unsur yang menopang usaha menciptakan nilai atau usaha memperbesar nilai barang disebut sebagai faktor produksi (Sukirno, 2002). Produksi sering didefinisikan sebagai pencipta guna, dimana guna berarti kemampuan barang atau jasa untuk memenuhi kebutuhan manusia. faktor produksi adalah benda-benda yang disediakan oleh alam atau diciptakan oleh manusia yang dapat digunakan untuk memproduksi barang dan jasa. Produksi pertanian yang optimal adalah yang mendatangkan produk yang menguntungkan. Ditinjau dari sudut ekonomi ini berarti biaya faktor-faktor yang berpengaruh pada produksi jauh lebih kecil bila dibandingkan dengan hasil yang diperoleh sehingga petani dapat memperoleh keuntungan dari usaha lainnya (Henry, 2013).

Biaya produksi adalah nilai dari semua faktor produksi yang digunakan, baik dalam bentuk benda maupun jasa selama proses produksi berlangsung. Adanya unsur-unsur produksi yang bersifat tetap dan tidak tetap dalam jangka pendek mengakibatkan munculnya dua kategori biaya, yaitu biaya tetap dan biaya variabel (Khazanani, 2011).

Menurut Mulyadi (2009) Biaya dapat dibagi berdasarkan sifatnya, artinya mengkaitkan antara pengeluaran yang harus di bayar dengan produk atau output yang dihasilkan yaitu: a. Biaya Tetap (Fixed Cost) adalah biaya yang besarnya tidak tergantung pada jumlah produksi.

b. Biaya Variabel (Variabel Cost) adalah biaya yang besarnya, tergantung pada tingkat produksi.

c. Biaya Total (Total Cost) merupakan penjumlahan dari biaya tetap dan biaya variabel dalam proses produksi.

$$
\mathbf{T C}=\mathbf{F C}+\mathbf{V C}
$$

Keterangan :

TC : Total Cost

TVC: Total Variabel Cost

TFC : Total Fixed Cost

C : Cost

$\mathrm{P} \quad$ : Price

\section{Konsep Harga}

Harga adalah variabel yang dapat dikendalikan dan dapat menentukan diterima tidaknya suatu produk sangat oleh konsumen. Murah atau mahalnya harga suatu produk sangat relatif sifatnya (Anoraga, 2000). Harga yaitu sejumlah kompensasi baik yang berupa uang maupun barang yang dibutuhkan untuk mendapatkan sejumlah kombinasi barang dan jasa.

Harga yang ditetapkan harus dapat menutup semua biaya yang telah dikeluarkan, jika harga ditetapkan terlalu tinggi maka kurang menguntungkan karena pembeli dan volume penjualan berkurang. Harga jual adalah sejumlah biaya yang dikeluarkan perusahaan untuk memproduksi suatu barang atau jasa ditambah dengan presentase laba yang diinginkan pedagang. Untuk mencapai laba yang diinginkan oleh pedagang, maka pedagang akan melakukan daya tarik konsumen dengan cara menentukan harga yang tepat untuk produk yang terjual. Harga yang tepat adalah harga yang sesuai dengan kualitas produk suatu barang, dan harga tersebut dapat memberikan kepuasan kepada konsumen (Supriyono, 2000).

\section{Rumusan Masalah}

Berdasarkan latar belakang yang telah diuraikan di atas, maka yang menjadi rumusan masalah dalam penelitian ini adalah berapa besar keuntungan yang diperoleh industri usaha gorengan dalam satu kali proses produksi di Kelurahan Bahu Kecamatan Malalayang Kota Manado. 


\section{Tujuan Penelitian}

Tujuan dari penelitian ini adalah menganalisis berapa keuntungan yang diterima industri usaha gorengan di Kelurahan Bahu Kecamatan Malalayang Kota Manado dalam satu kali proses produksi.

\section{Manfaat Penelitian}

Manfaat dari penelitian ini adalah agar dapat memberikan informasi bagi pihak-pihak yang memerlukannya untuk menambah wawasan dan pengetahuan yang lebih luas mengenai usaha gorengan. serta diharapkan dapat digunakan sebagai bahan kajian untuk peningkatan usaha dalam rangka mencapai keuntungan yang maksimal.

\section{METODE PENELITIAN}

\section{Lokasi dan Waktu Penelitian}

Penelitian ini dilakukan selama 3 bulan yaitu sejak bulan Oktober - Desember 2019 dengan lokasi penelitian dilaksanakan di Kelurahan Bahu Kecamatan Malalayang Kota Manado.

\section{Metode Pengumpulan Data}

Metode penelitian yang digunakan dalam penelitian ini adalah studi kasus pada usaha di Kelurahan Bahu Kecamatan Malalayang Kota Manado. Data yang di ambil adalah data primer menggunakan teknik wawancara langsung dengan pemilik usaha. menggunakan daftar pertanyaan yang telah dipersiapkan terlebih dahulu.

\section{Konsepsi pengukuran variabel}

Variabel-variabel yang diukur dalam penelitian ini adalah :

\section{Produksi}

Yaitu, jumlah produksi gorengan yang dihasilkan dalam satu kali produksi dihitung dalam satuan buah.

2. Harga Jual

Harga jual dari produksi gorengan yang dihasilkan dihitung dalam satuan rupiah per buah (Rp/buah).

3. Biaya Produksi Rp

Yaitu, besarnya biaya yang dikeluarkan dalam pembuatan gorengan setiap kali produksi yang terdiri dari: a.) Biaya tetap

- Penyusutan alat, yaitu nilai penyusutan selama 1 tahun dari alat-alat yang digunakan. Alat-alat yang digunakan dalam proses pembuatan gorengan adalah wajan, kompor, pisau dan lesung.

Nilai penyusutan dihitung dengan menggunakan metode garis lurus atau straight line method.

$$
\text { Biaya penyusutan }=\frac{\text { Harga pembelian }- \text { Nilai sisa }}{\text { Umur Ekonomis }}
$$

b.) Biaya Variabel

- Biaya bahan baku, biaya tenaga kerja dan biaya sewa tempat

c.) Biaya Tambahan

Biaya pembantu dalam proses industri ini yaitu berupa Minyak kelapa, Gas elpiji 3kg, Terigu, Garam, Rica, Tomat, Kantong plastik.

\section{Metode Analisis Data}

Data yang dikumpulkan dalam penelitian ini kemudian dianalisis dengan menggunakan analisis keuntungan yaitu dengan menghitung selisih antara penerimaan dengan biaya yang digunakan. Data yang dikumpulkan akan disajikan dalam bentuk variabel dan di analisis secara deskriptif. Dan kemudian di lanjutkan dengan rumus Analisis Revenue Cost Ratio (R/C) untuk mengukur benar keuntungan digunakan rumus sebagai berikut :

$$
\pi=\mathbf{T R}-\mathbf{T C}
$$

Dimana :

$$
\begin{array}{ll}
\pi & =\text { Profit }(\text { Keuntungan) } \\
\text { TR } & =\text { Total Revenue }(\text { Total Penerimaan) } \\
\text { TC } & =\text { Total Cost }(\text { Total Biaya })
\end{array}
$$

Dimana :

$$
\mathbf{T R}=\mathbf{Q} \cdot \mathbf{P q}
$$

TR $=$ Total Penerimaan

$\mathrm{Q} \quad=$ Jumlah Produksi yang dijual

$\mathrm{Pq} \quad=$ Harga tiap satuan produk

Dimana :

$$
\mathbf{T C}=\mathbf{F C}+\mathrm{VC}
$$

TC $($ Total Cost $)=$ Total Biaya

FC $($ Fixed Cost $)=$ Biaya Tetap

$\mathrm{VC}($ Variabel Cost $) \quad=$ Biaya Variabel

Kemudian untuk mengetahui apakah usaha gorengan ini menguntungkan atau tidak dapat digunakan dengan rumus :

$$
\begin{aligned}
\mathbf{a} & =\mathbf{R} / \mathbf{C} \\
& =(\text { Py.Y }) /(\mathbf{F C}+\text { VC })
\end{aligned}
$$


Apabila :

$\mathrm{R} / \mathrm{C}=1$, Berarti industri ini tidak untung atau tidak rugi

$\mathrm{R} / \mathrm{C}<1$, Berarti industri ini rugi

$\mathrm{R} / \mathrm{C}>1$, Berarti industri ini untung

Dimana :

$$
\begin{array}{ll}
\mathrm{a} & =\text { Revenue Cost Ratio } \\
\mathrm{R} & =\text { Revenue / Penerimaan } \\
\mathrm{C} & =\text { Cost / Biaya } \\
\mathrm{Py} & =\text { Output Price / Harga Produksi } \\
\mathrm{Y} & =\text { Output / Jumlah Produksi } \\
\mathrm{FC} & =\text { Fixed Cost / Biaya Tetap }
\end{array}
$$

\section{HASIL DAN PEMBAHASAN}

\section{Deskripsi Usaha Gorengan "Ibu Nouke" di Kelurahan Bahu Kecamatan Malalayang Kota Manado}

Usaha gorengan ini berdiri sejak tahun 2004 yang dikelola oleh Ibu Nouke, sebelumya Ibu Nouke bekerja sebagai petani dan juga berjualan gorengan keliling dikampung, ketika datang merantau ke Manado Ibu Nouke langsung memulai usaha gorengan. Rumah yang digunakan untuk usaha gorengan hanyalah sewa hingga sampai sekarang. Usaha gorengan Ibu Nouke ini bertempat di Jalan Pulau Bunaken, Lingkungan II, Kelurahan Bahu Kecamatan Malalayang Kota Manado.

Gorengan "Ibu Nouke" berloksai di Kelurahan Bahu, Tepatnya belakang Gereja Imanuel. Gorengan "Ibu Nouke " ini sudah beroperasi kurang lebih 15 tahun. Dan untuk rasa dan kwalitasnya tidak di ragukan lagi, karena selain menggunakan bahan baku yang berkwalitas bagus. Proses pengolahannya juga sangat higenis. Dan pastinya pengelolah gorengannya juga sudah sangat berpengalaman yaitu Ibu Nouke sendiri.

Selain mempunyai rasa yang sangat enak dan gurih, gorengan "Ibu Nouke" juga di lengkapi dengan sambel atau bahasa Manado Dabu-dabu ikan roa, oleh karena itu gorengan "Ibu Nouke" ini sangat di minati semua kalangan baik anak-anak, muda-mudi, orang tua. Dan juga untuk harga sangat mudah di jangkau yaitu Rp. 1.500 /satu buah.

Sebelumnya pembelian bahan baku pisang, tahu dan ubi usaha gorengan ini sebesar Rp 300.000/pengambilan dan di bagi pengambilan pisang 20 sisir atau 400 buah sebesar Rp. 200.000, dan pengambilan tahu satu ember ada 120 buah jadi biaya tahu sebesar Rp. 60.000, dan biaya ubi Rp. 40.000/pengambilan dapat dua kantong plastik, satu kantong plastik berisi enam buah ubi jadi biaya ubi adalah sebesar Rp. 20.000, dalam satu hari produksi. Dan untuk pembelian bahan baku pisang, tahu dan ubi di ambil langsung di pasar tradisional pinasungkukan karombasan.

Hasil keuntungan dari usaha gorengan diakui pemilik mampu untuk memenuhi kebutuhan pangan (konsumsi sehari-hari) keluarga, membiayai sekolah anak serta cucu, modal untuk kesinambungan usaha serta hasil yang didapatkan ditabung untuk kebutuhan keluarga kedepan.

\section{Produksi, Harga, dan Biaya Produksi}

\section{Produksi}

Dasarnya setiap industri dalam meningkatkan produksinya bertujuan untuk meningkatkan keuntungan yang diterimanya. Hasil produksi yang diperoleh dinilai dari biaya yang dikeluarkan dan penerimaan yang diperoleh. Dalam hasil gorengan pisang, gorengan tahu dan gorengan ubi. Dapat dilihat dalam Tabel 1.

Tabel 1. Produksi Usaha Gorengan "Ibu Nouke" (Perhari)

\begin{tabular}{lc}
\hline Jenis Produk & Jumlah (Buah) \\
\hline Pisang & 400 \\
Tahu & 120 \\
Ubi & 120 \\
\hline Total & $\mathbf{6 4 0}$ \\
\hline
\end{tabular}

Tabel 1 menunjukkan bahwa produk pisang yang digunakan untuk digoreng sebanyak 400 buah, dan untuk produk tahu yang akan di gunakan untuk digoreng sebanyak 120 buah, dan untuk produk ubi yang akan di gunakan untuk digoreng sebanyak 120 buah. Jadi jumlah total produksi usaha gorengan yang dipakai sebanyak 640 buah.

\section{Harga Jual}

Harga merupakan persetujuan antara pembeli dengan penjual dalam penjual satu buah tertentu. Untuk harga / (satu buah) gorengan pisang yaitu Rp. 1.500, gorengan tahu Rp. 1.500 dan gorengan ubi Rp.1.500. 


\section{Biaya Produksi}

Biaya produksi merupakan keseluruhan biaya yang digunakan untuk membiayai keseluruhan proses usaha tersebut. Biaya produksi untuk mengelolah gorengan terdiri dari biaya variabel (Variable Cost) dan biaya tetap (Fixed Cost). Dalam penelitian ini menunjukkan bahwa dalam produksi usaha gorengan mengeluarkan beberapa biaya untuk menunjang kegiatan produksi yaitu biaya tetap, berupa biaya penyusutan alat, dan biaya variabel.

\section{Biaya Tetap}

\section{Biaya}

Biaya tetap $(F C)$ yang dimaksud dalam penelitian ini adalah biaya yang tidak habis dalam satu kali proses produksi, tetapi hanya mengalami penyusutan atau yang disebut sebagai biaya investasi seperti pengadaan peralatan. Untuk menunjak keberlangsungan industri pembutan gorengan. Biaya tetap dalam pembuatan usaha gorengan diperhitungkan sebagai penyusutan kerja dari alat-alat produksi yang digunakan dalam memproduksi gorengan. Penyusutan dapat dihitung berdasarkan umur ekonomis dari alatalat produksi. Untuk mengetahui nilai ekonomis dari masing-masing peralatan yang digunakan dalam pembuatan gorengan, maka dihitung nilai penyusutan dalam satu kali proses produksi. Penyusutan dihitung menggunakan metode garis lurus yaitu nilai awal dari peralatan dikurangi dengan nilai sisa kemudian dibagi dengan umur ekonomis dari peralatan tersebut. Nilai awal diperoleh dari biaya yang digunakan untuk membeli peralatan tersebut sedangkan umur ekonomis dilihat dari lamanya penggunaan peralatan tersebut masih menguntungkan.

\footnotetext{
Alat

Penyusutan alat merupakan biaya yang perlu dimasukan kedalam perhitungan biaya tetap. Biaya penyusutan alat yaitu pengurangan nilai yang disebabkan oleh pemakaian alat selama proses berlangsung. Penyusutan yang dihitung adalah umur teknis alat berdasarkan pemakaian alat-alat produksi milik sendiri dapat dilihat pada Tabel 2.
}

Tabel 2. Nilai Penyusutan Alat Pada Usaha Gorengan "Ibu Nouke"

\begin{tabular}{lc}
\hline Jenis Produk & Penyusutan Alat \\
\hline Wajan & 101,37 \\
Kompor gas besar & 71,23 \\
\hline Total & $\mathbf{1 7 2 , 6 0}$ \\
\hline
\end{tabular}

Tabel 2 menunjukkan bahwa nilai penyusutan alat yaitu sebesar Rp.101,37/hari. Wajan yang digunakan adalah wajan besar dengan ukuran $75 \mathrm{~cm}$ dan tinggi $25 \mathrm{~cm}$ dipakai untuk menggoreng gorengan, dan harga wajan sebesar Rp. 560.000, dan untuk harga ekonomisnya sebesar Rp. 5.000, dan Kompor rinaai besar merupakan salah satu kompor terbaik untuk bidang komersial. Bertipe low pressure atau tekanan gas yang rendah, tetapi menghasilkan api yng besar. Harga kompor sebesar Rp. 400.000, dan untuk harga ekonomisnya sebesar Rp. 10.000.

\section{Biaya Variabel Pada Usaha Gorengan "Ibu Nouke"}

Biaya variabel adalah yang digunakan dalam satu kali proses produksi dan besar kecilnya biaya dipengaruhi oleh produksi yang diperoleh. dalam biaya variabel ini yang dihitung adalah biaya bahan baku, biaya tenaga kerja, biaya sewa tempat, biaya tambahan/penolong seperti minyak kelapa, gas elpiji $3 \mathrm{~kg}$, terigu, garam, rica, tomat, kantong plastic kecil dan kantong plastic sedang biaya variabel dapat dilihat pada Tabel 3.

Tabel 3. Biaya Variabel pada Usaha Gorengan "Ibu Nouke"

\begin{tabular}{lr}
\hline Biaya-biaya Produksi & Rata-rata Biaya (Rp) \\
\hline Biaya Bahan Baku & 300.000 \\
Biaya Tenaga Kerja & 180.000 \\
Biaya sewa tempat & 23.333 \\
Biaya Tambahan/Penolong : & \\
a. Minyak Goreng & 66.666 \\
b. Gas Elpiji 3kg & 36.000 \\
c. Terigu & 50.000 \\
d. Garam & 4.000 \\
e. Rica $1 / 2 \mathrm{~kg}$ & 15.000 \\
f. Tomat $1 \mathrm{~kg}$ & 5.000 \\
g. Ikan roa & 4.166 \\
h. Kecap & 2.000 \\
i. Sayur kubis & 5.000 \\
j. Wortel & 5.000 \\
k. Kantong plastik kecil & 7.500 \\
l. Kantong plastik sedang & 6.000 \\
\hline Total Biaya Variabel & $\mathbf{7 0 9 . 6 6 5}$ \\
\hline
\end{tabular}


Tabel 3 menunjukkan bahwa biaya yang dikeluarkan dalam proses pembuatan gorengan pisang, tahu, dan ubi yaitu biaya bahan baku sebesar Rp. 300.000/pengambilan dan di bagi pengambilan pisang 20 sisir atau 400 buah sebesar Rp. 200.000, dan pengambilan tahu satu ember ada 120 buah jadi biaya tahu sebesar Rp. 60.000, dan biaya ubi Rp. 40.000/pengambilan dapat dua kantong plastik, satu kantong plastik berisi enam buah ubi jadi biaya ubi adalah sebesar Rp. 20.000, dan biaya tenaga kerja adalah sebesar Rp. 180.000, dan pembayaran tenaga kerja ada tiga orang dan masing-masing dibayar sebesar Rp. 60.000,dan biaya sewa tempat adalah sebesar $\mathrm{Rp}$. 700.000/bulan biaya sewa tempat dan dihitung dalam satu kali proses produksi dalam satu hari sehingga biaya sewa tempat adalah sebesar Rp. 23.333, dan biaya tambahan untuk pembuatan gorengan yaitu biaya minyak goreng adalah sebesar Rp. 200.000/pengambilan minyak kelapa dan dihitung dengan hasil pemakaian dalam satu kali proses produksi dalam satu hari sehingga biaya minyak kelapa adalah sebesar Rp. 66.666, dan biaya gas elpiji $3 \mathrm{~kg}$ adalah sebesar Rp. 18.000. Gas elpiji $3 \mathrm{~kg}$ yang digunakan dalam pemakaian yaitu 2 tabung gas elpiji dalam proses produksi gorengan, Sehingga dalam penelitian ini nilai gas elpiji adalah sebesar Rp. 36.000, dan biaya terigu pembuatan gorengan adalah sebesar Rp. 150.000/ pengambilan terigu dan dihitung dengan hasil pemakaian dalam satu kali proses produksi dalam satu hari sehingga biaya terigu adalah sebesar Rp. 50.000, dan biaya garam adalah Rp. 4.000/pengambilan garam dan dihitung dengan hasil pemakaian dalam satu kali proses dalam satu hari sehingga biaya garam adalah sebesar Rp. 2.000, dan biaya rica adalah sebesar Rp. 15.000/pemakaian, dan biaya tomat adalah sebesar Rp. 5.000/pemakaian, dan biaya ikan roa sebesar Rp. 25.000/pengambilan ikan roa dan dihitung dengan hasil pemakaian dalam satu kali proses dalam satu hari sehingga biaya ikan roa adalah sebesar Rp. 4.166, dan biaya kecap adalah sebesar Rp. 6.000/pengambilan dan dihitung dengan hasil pemakaian dalam satu kali proses dalam satu hari sehingga biaya kecap adalah sebesar Rp. 2.000, dan biaya sayur kubis adalah sebesar Rp. 5.000/pengambilan, dan biaya wortel adalah sebesar Rp. 5000/ pengambilan, dan biaya kantong plastic kecil adalah sebesar Rp. 1.500, dan kantong plastik kecil yang digunakan dalam pemakaian yaitu lima kantong plastik kecil dalam proses pembukusan, Sehingga biaya adalah sebesar Rp. 7.500, dan biaya kantong plastik sedang adalah sebesar Rp. 3.000. Kantong plastik sedang yang digunakan dalam pemakaian yaitu dua kantong plastik sedang dalam proses pembukusan, sehingga biaya adalah sebesar Rp. 6.000 Total rata-rata biaya variabel yang dikeluarkan adalah sebesar Rp. 709.665.

\section{Biaya bahan baku}

Biaya bahan baku dalam proses pembuatan gorengan ini merupakan salah satu komponen biaya produksi yang diperhitung-kan, biaya bahan baku dalam pembuatan gorengan ini yaitu pisang, tahu dan ubi.

\section{Penerimaan}

Penerimaan adalah jumlah produksi dikalikan dengan harga jual yang berlaku. Dalam kegiatan usaha ini selalu meningkatkan produksi dengan harapan bahwa pendapatan yang diterima akan naik sejalan dengan bertambahnya produksi yang dihasilkan. Penerimaan berkaitan erat dengan volume produksi dan harga jual, oleh karena itu penerimaan merupakan hasil perkalian antara harga jual yang berlaku dalam produksi. Dapat dilihat pada Tabel 4.

\begin{tabular}{lc} 
Tabel 4. Penerimaan Usaha Gorengan \\
\hline Jenis Produk & Penerimaan \\
\hline Pisang & 600.000 \\
Tahu & 180.000 \\
Ubi & 180.000 \\
\hline Total & $\mathbf{9 6 0 . 0 0 0}$ \\
\hline
\end{tabular}

Tabel 4 menunjukkan bahwa harga gorengan 1500 /buah, jadi hasil gorengan pisang 400 buah adalah sebesar Rp. 600.00,dan hasil gorengan tahu 120 buah adalah sebesar Rp. 180.000, dan hasil gorengan ubi 120 buah adalah sebesar Rp. 180.000. Total produksi gorengan adalah sebesar Rp. 960.00.

\section{Keuntungan}

Keuntungan yang diperoleh sangat tergantung dari jumlah penerimaan yang diterima dikurangi dengan biaya yang dikeluarkan, besarnya penerimaan yang didapat merupakan hasil perkalian antara harga jual 
produk dengan jumlah produksi yang dihasilkan sehingga tinggi produksi dengan biaya semakin kecil dan harga akan mempengaruhi keuntungan. Dalam penelitian ini dapat dilihat pada Tabel 5.

\begin{tabular}{lc}
\multicolumn{2}{l}{ Tabel 5. Keuntungan Usaha Gorengan "Ibu Nouke" } \\
\hline Uraian & Jumlah \\
\hline Penerimaan & 960.000 \\
Total Biaya & 709.665 \\
\hline Keutungan & $\mathbf{2 5 0 . 3 3 5}$ \\
\hline
\end{tabular}

Tabel 5 menunjukkan bahwa total Keuntungan dari Gorengan pisang, Gorengan tahu, dan gorengan Ubi. Dengan Penerimaan sebesar Rp. 960.000, Besar Biaya Rp. 709.665, dan Keuntungan yang di dapat dalam usaha gorengan dalam satu kali proses produksi adalah sebesar Rp. 250.335 .

\section{Revenue Cost Ratio}

Tingkat keuntungan ekonomi dapat diketahui dengan menggunakan Analisis Revenue Cost Ratio (R/C ratio) adalah perbandingan antara penerimaan dan biaya, ratio yang menjadi parameternya adalah nilai $\mathrm{R} / \mathrm{C}=1$ berarti usaha tidak untung dan tidak rugi, nilai $\mathrm{R} / \mathrm{C}<1$ berarti usaha rugi, nilai $\mathrm{R} / \mathrm{C}>1$ berarti usaha untung. Nilai R/C Usaha Industri Usaha Gorengan di Kelurahan Bahu Kecamatan Malalayang dapat dilihat bahwa nilai rata-rata $\mathrm{R} / \mathrm{C}$ dari produksi gorengan ini menunjukkan angka $>1$. Nilai R/C dari usaha gorengan ini adalah 1.35 maka usaha gorengan ini menguntungkan.

\section{KESIMPULAN DAN SARAN}

\section{Kesimpulan}

Penelitian ini dapat disimpulkan bahwa usaha Gorengan "Ibu Nouke" di Kelurahan Bahu Kecamatan Malalayang Kota Manado ini menguntungkan. Usaha Industri Gorengan ini mengeluarkan total rata-rata biaya dalam sekali produksi adalah sebesar Rp. 709.665, total rata-rata penerimaan adalah sebesar Rp.960.000, dan mendapatkan total rata-rata keuntungan adalah sebesar Rp. 250.335 dalam sekali produksi. dan menggunakan R/C Ratio menjadi 1.35 yang berarti industri ini menguntungkan.

\section{Saran}

Berkaitan dengan hasil penelitian ini, untuk pedagang gorengan hendaknya lebih menjaga dan memperhatikan dagangannya mengingat peranan gorengan yang cukup penting dalam masyarakat, dan usaha gorengan ini kiranya mempertahankan soal kualitas supaya konsumen puas dalam membeli gorengan tersebut. Dan kepada pemerintah, sebaiknya harga bahan baku gorengan dijaga, agar tetap stabil. Sehingga masyarakat kaum menengah ke bawah masih dapat memperoleh keuntungan dari hasil dagangannya. Kepada peneliti lain diharapkan agar melakukan penelitian sejenis agar menjadi bahan perbandingan.

\section{DAFTAR PUSTAKA}

Adriani, F. Y. dan Nasriati. 2011. Teknologi Pengolahan Tepung Pisang. Balai Pengkajian Teknologi Pertanian (BPTP), Lampung.

Anoraga, P. \& J. Sudantoko. 2002. Koperasi Kewirausahaan dan Usaha Kecil. Rineka Cipta. Jakarta.

Bardosono. 2014. Produksi Tanaman Buah di Indonesia Tahun 2009 - 2013. http:// horti.pertanian.go.id/node/254.7 September 2015.

Cahanar, P. \& Suhanda, I. 2006. Makan Sehat Hidup Sehat, Jakarta, Kompas Media Utama.

Henry, S. 2013. Pengantar Ilmu Ekonomi. CAPS. Yogyakarta.

Khazanani, A., SBM, N., \& Nugroho, S. B. M. Nugroho. 2011. Analisis Efisiensi Penggunaan Faktor-Faktor Produksi Usahatani Cabai Kabupaten Temanggung (Studi Kasus di Desa Gondosuli Kecamatan Bulu Kabupaten Temanggung). Diss. Universitas Diponegoro.

Santoso, W., Utami, P. dan Dumasari. 2009. Analisis Pendapatan dan Biaya Produksi Agroindustri Tahu di Desa Pandansari kecamatan Ajibarang Kabupaten Banyumas. Jurnal. Fakultas Pertanian. Universitas Muhammadiayah Purworkert.

Simamora, 2000. Akutansi. Basis Pengembalian Keputusan Bisnis. Jild Satu. Salemba Empat. Jakarta.

Sukirno, S. 2002. Pengantar Teori Makro Ekonomi. PT. Raja Grafndo. Jakarta.

Suparta, N. 2010. Memantapkan Strategi Pengelolaan Pertanian. Denpasar: Pustaka Nayottama.

Supriyono, R.A, 2000. Akutansi Biaya. Perencanaan dan Pengendalian Biaya serta pembuatan keputusan, Edisi kedua, BPFE, Yogyakarta. 